\title{
Intensive Insulin Therapy for Critically III Patients
}

\author{
Kelly S Lewis, Sandra L Kane-Gill, Mary Beth Bobek, and Joseph F Dasta
}

OBJECTIVE: To evaluate the clinical outcomes of glycemic control of intensive insulin therapy and recommend its place in the management of critically ill patients.

DATA SOURCES: Searches of MEDLINE (1966-March 2004) and Cochrane Library, as well as an extensive manual review of abstracts were performed using the key search terms hyperglycemia, insulin, intensive care unit, critically ill, outcomes, and guidelines and algorithms.

STUDY SELECTION AND DATA EXTRACTION: All articles identified from the data sources were evaluated and deemed relevant if they included and assessed clinical outcomes.

DATA SYNTHESIS: Mortality among patients with prolonged critical illness exceeds $20 \%$, and most deaths are attributable to sepsis and multisystem organ failure. Hyperglycemia is common in critically ill patients, even in those with no history of diabetes mellitus. Maintaining normoglycemia with insulin in critically ill patients has been shown to improve neurologic, cardiovascular, and infectious outcomes. Most importantly, morbidity and mortality are reduced with aggressive insulin therapy. This information can be implemented into protocols to maintain strict control of glucose.

CONCLUSIONS: Use of insulin protocols in critically ill patients improves blood glucose control and reduces morbidity and mortality in critically ill populations. Glucose levels in critically ill patients should be controlled through implementation of insulin protocols with the goal to achieve normoglycemia, regardless of a history of diabetes. Frequent monitoring is imperative to avoid hypoglycemia.

KEY WORDS: hyperglycemia, insulin infusions, intensive care unit.

Ann Pharmacother 2004;38:1243-51.

Published Online, 8 Jun 2004, www.theannals.com, DOI 10.1345/aph.1D211

$\mathrm{T}$ here is a pressing need to improve patient outcomes in intensive care units (ICUs). ICUs comprise 3-5\% of hospital beds; however, a disproportionate amount of hospital resources (20-30\%) are consumed there. ${ }^{1}$ Pharmaceuticals contribute substantially to the total costs, particularly as expensive new biotechnology drugs are approved for use. ${ }^{2}$ The search continues for optimal low-cost therapies. Until recently, no single drug has significantly impacted survival above that afforded by aggressive hemodynamic support, ventilation, and appropriate antibiotics. Although one recently approved agent, drotrecogin alfa, may reduce

Author information provided at the end of the text. mortality in severe sepsis, the clinical benefit is associated with considerable acquisition costs. ${ }^{3}$ Overall, ICU mortality remains $>20 \%$ despite our best efforts. ${ }^{4}$

Hyperglycemia is common in critically ill patients with and without diabetes. ${ }^{5}$ Elevated blood glucose (BG) concentrations are associated with increased morbidity and mortality after burns, ${ }^{6}$ surgery, ${ }^{7}$ stroke, myocardial infarction (MI), and head trauma ${ }^{8-13}$ Hyperglycemia is believed to increase infarct size in both MI and stroke., ${ }^{911,12}$ Admission BG concentration is an independent predictor for mortality in women undergoing coronary artery bypass surgery. ${ }^{14}$ In addition, there is evidence that hyperglycemia increases the risk of nosocomial infections and may be a causal factor. ${ }^{15}$ 
While the aforementioned outcomes data describe association, not cause, aggressive treatment of hyperglycemia positively impacts outcomes in critically ill patients. The technology to deliver tight glycemic control in the critical care setting is widely available; implementing a safe and effective program is necessary. The purpose of this paper is to review the pathophysiology and clinical outcomes of hyperglycemia in various populations of critically ill patients and discuss the impact of strict glucose control on clinical outcomes, as well as to recommend the role of insulin protocols in the ICU.

\section{Data Sources}

Searches of MEDLINE (1966-March 2004) and Cochrane Library, as well as an extensive manual review of abstracts were performed using the key search terms hyperglycemia, insulin, intensive care unit, critically ill, outcomes, and guidelines and algorithms. All articles identified from the data sources were evaluated and deemed relevant if they included and assessed clinical outcomes.

\section{Pathophysiology of Hyperglycemia in Critical IIIness}

The concept of stress-induced hyperglycemia, typically defined as BG concentrations $>200 \mathrm{mg} / \mathrm{dL}$, has been described for almost 150 years. Hyperglycemia in critical illness is associated with infection, medications, and other conditions.

Stress associated with acute illness increases the concentration of counterregulatory hormones and cytokines (Table 1). Epinephrine mediates stress hyperglycemia by altering postreceptor signaling, resulting in insulin resistance. In addition, epinephrine increases gluconeogenesis and directly suppresses insulin secretion. Glucagon increases gluconeogenesis and hepatic glycogenolysis. Studies have demonstrated that hyperglycemia after trauma is primarily caused by increased hepatic glucose production and insulin resistance rather than impaired glucose clearance. ${ }^{16-20}$ In early studies, infusing epinephrine, glucagon, and cortisol resulted in a 60-80\% increase in BG, as well as a $100 \%$ increase in gluconeogenesis despite hyperinsulinemia. The combination of hormone infusions resulted in a threefold greater increase in BG compared with responses to individual hormones. ${ }^{21,22}$ Similar results are reported in animal models, where net hepatic glucose production was significantly increased but peripheral glucose clearance was unchanged despite a threefold increase in insulin concentration. Gluconeogenesis accounted for the vast majority of hyperglycemia occurrences. ${ }^{23}$ In burn injury, glucagon is the primary stimulant of excessive glucose production. ${ }^{24}$ Glucose may remain elevated for weeks, resulting in hyperglycemia. ${ }^{25}$

Severely ill patients have increased production of various cytokines, particularly tumor necrosis factor- $\alpha$ (TNF$\alpha$ ), interleukin (IL)-1, and IL-6, which leads to stress-induced hyperglycemia. Surgery and critical illness promote the release of these inflammatory mediators from mononuclear cells, contributing to insulin resistance and hyperglycemia. TNF- $\alpha$ causes insulin resistance in both liver and skeletal muscle via modification of signaling properties of insulin receptor substrates. ${ }^{26}$

Medications frequently administered in the ICU or operating room may cause hyperglycemia. Exogenously administered epinephrine and norepinephrine exacerbate hyperglycemia via their $\alpha$-adrenergic effects. ${ }^{27,28}$ Other therapies that can result in hyperglycemia include corticosteroids, other sympathomimetics, and immunosuppressants (eg, cyclosporine, tacrolimus). ${ }^{29}$

The influence of corticosteroids on glucose can be observed in the transplant population. Hepatic glucose production is increased in both steroid-treated insulin-dependent diabetes mellitus (IDDM) patients who have received a renal transplant and IDDM patients without nephropathy compared with nondiabetic renal graft recipients and healthy controls ( $p$ < 0.01).$^{30}$ Insulin-stimulated glucose disposal was reduced in patients with IDDM regardless of whether they had undergone renal transplantation and in nondiabetic patients who received transplants versus healthy controls $(\mathrm{p}<0.05)$. This reduction was mainly due to impairment in nonoxidative glucose metabolism (ie, glycogen synthesis). IDDM patients without nephropathy show both hepatic and peripheral insulin resistance; further increases in insulin resistance are caused by corticosteroids and can be corrected by increasing insulin doses. Interestingly, nondiabetic, steroid-treated renal graft recipients show insulin resistance comparable to that of IDDM patients.

Hyperglycemia can result from parenteral and enteral nutrition and from dextrose solutions used for drug or fluid administration. Nondiabetic hospitalized patients who receive dextrose solutions at rates $>4 \mathrm{~g} / \mathrm{kg} / \mathrm{min}$ (eg, total par-

\begin{tabular}{|c|c|}
\hline \multicolumn{2}{|c|}{$\begin{array}{l}\text { Table 1. Counterregulatory Hormones Involved in the } \\
\text { Hyperglycemic Response to Critical Illness }\end{array}$} \\
\hline Hormone & Mechanism \\
\hline Epinephrine & $\begin{array}{l}\text { skeletal muscle insulin resistance via altered } \\
\text { postreceptor signaling } \\
\text { increased gluconeogenesis } \\
\text { increased skeletal muscle and hepatic } \\
\text { glycogenolysis } \\
\text { increased lipolysis; increased free fatty acids } \\
\text { direct suppression of insulin secretion }\end{array}$ \\
\hline Glucagon & $\begin{array}{l}\text { increased gluconeogenesis } \\
\text { increased hepatic glycogenolysis }\end{array}$ \\
\hline Glucocorticoids & $\begin{array}{l}\text { skeletal muscle insulin resistance } \\
\text { increased lipolysis } \\
\text { increased gluconeogenesis }\end{array}$ \\
\hline Growth hormone & $\begin{array}{l}\text { skeletal muscle insulin resistance } \\
\text { increased lipolysis } \\
\text { increased gluconeogenesis }\end{array}$ \\
\hline Norepinephrine & $\begin{array}{l}\text { increased lipolysis } \\
\text { increased gluconeogenesis; marked hypergly- } \\
\text { cemia only at high concentrations }\end{array}$ \\
\hline $\begin{array}{l}\text { Tumor necrosis } \\
\text { factor }\end{array}$ & $\begin{array}{l}\text { skeletal muscle insulin resistance via altered } \\
\text { postreceptor signaling } \\
\text { hepatic insulin resistance }\end{array}$ \\
\hline
\end{tabular}


enteral nutrition solutions) have a 50\% chance of developing hyperglycemia. ${ }^{31}$ Dialysis solutions are a hidden source of glucose; systemic absorption of $80 \mathrm{~g} /$ day has been reported. ${ }^{19,32,33}$ The hyperglycemic response to surgery can also be altered by the anesthetic technique. For example, epidural analgesia with local anesthetic established before surgery inhibits the increase in BG concentration during abdominal surgery compared with inhaled anesthesia. ${ }^{34,35}$ Furthermore, intravenous anesthesia with large or moderate doses of opioids attenuates the hyperglycemic response to surgery. ${ }^{36,37}$ In contrast, isoflurane anesthesia results in both impaired glucose clearance and increased glucose production. ${ }^{38}$ Hypothermia induced by cardioplegia solutions during coronary artery bypass surgery also inhibits insulin responses to hyperglycemia. ${ }^{39}$

Surgical animal models reveal that insulin resistance is the key mechanism for releasing glucose into the circulation, thereby increasing intravascular volume. ${ }^{17}$ Surgery produces insulin resistance in both skeletal muscle and adipose tissue. ${ }^{18,19}$ Insulin resistance develops in proportion to the duration of surgery and may persist for weeks. ${ }^{18}$ Studies of thermal-induced trauma demonstrate that serum insulin levels remain significantly high 3 weeks after injury, consistent with the presence of an insulin-resistant state, resulting in increased glucose concentrations. ${ }^{16}$ In contrast, studies of septic and thermal injury-induced insulin resistance differ in that peripheral glucose uptake in sepsis is refractory to insulin stimulation, whereas nonseptic burn injury is not. ${ }^{40}$ Hyperglycemia associated with insulin resistance has also been demonstrated in critically ill patients with no history of diabetes. ${ }^{41}$

\section{Physiologic Beneficial Effects of Insulin}

In addition to its hypoglycemic action, insulin promotes muscle protein synthesis ${ }^{42}$ and inhibits lipolysis. ${ }^{43}$ Insulin also produces a variety of antiinflammatory responses. Intensive insulin therapy significantly reduces $\mathrm{C}$-reactive protein levels $(p<0.02)$ and increases mannose-binding lectin $(\mathrm{p}<0.02)$ from baseline in patients requiring ICU care for $>5$ days. ${ }^{44}$ It suppresses nuclear factor $\kappa-\beta$ expression and free radical generation, and enhances endothelial nitric oxide production. ${ }^{45}$ Although glucose has proinflammatory properties that result in production of TNF- $\alpha$ and other cytokines, insulin may have a cardioprotective effect as it reduces thromboxane $\mathrm{A}_{2}$ production and plasma plasminogen activator inhibitor- 1 activity, thereby decreasing platelet aggregation and increasing fibrinolysis. ${ }^{46-48} \mathrm{TNF}$ causes endothelial dysfunction and apoptosis, triggers procoagulant activity and fibrin deposition, and enhances nitric oxide synthesis in a variety of cells. Administration of exogenous insulin suppresses TNF production in a dosedependent manner. ${ }^{49}$ These effects may explain the increased mortality and incidence of cardiogenic shock in patients who have experienced acute MI and developed stress hyperglycemia, even though they are not diabetic. ${ }^{9}$ Insulin has been shown to stimulate the activity of enzymes essential in the formation of prostaglandin $\mathrm{E}_{1}$ and $\mathrm{I}_{2}$ precursors, which are potent vasodilators and inhibitors of platelet aggregation. ${ }^{50}$ These precursors suppress the synthesis and production of TNF and IL-2 by human T cells.

\section{Outcomes}

\section{NEUROLOGY}

Changes in BG concentrations in critically ill patients have various effects on neurologic function. Hyperglycemia has been reported to augment ischemic brain injury and worsen outcomes in many animal and human studies. . 10,11,13,51 $^{-1}$ One study evaluated 267 nondiabetic patients with nonpenetrating head injuries. ${ }^{52} \mathrm{~A}$ significant relationship was found between postoperative BG concentrations, pupillary reaction, and maximal intracranial pressure during the first 24 hours. Among patients with more severe head injury, BG levels $>200 \mathrm{mg} / \mathrm{dL}$ were associated with worse outcomes. The postoperative BG concentration was an independent predictor of outcomes at 6 months. Elevated brain glucose concentrations resulting from hyperglycemia, in conjunction with an ischemia-induced shift to anaerobic glycolysis, led to more severe elevations of brain lactic acid concentrations and more profound acidosis.

There are conflicting results concerning the effects of hyperglycemia on focal brain ischemia ${ }^{53,54}$; however, when restricting analysis to reversible ischemia models, there is a consistent association between higher BG concentrations and larger infarct size. ${ }^{55-57}$ Possible mechanisms of this effect include increased brain tissue acidosis, which may contribute to progressing infarction, increased blood-brain barrier permeability, and increased hemorrhagic transformation of the infarct. ${ }^{58-60}$ Negative neurologic outcomes associated with hyperglycemia include the evolution of hypoperfused tissue, greater infarct size, and worse functional outcome in patients with acute ischemic stroke, ${ }^{10,61}$ longer hospital stays, and higher hospital charges. ${ }^{13,61}$

Hyperglycemia is also independently associated with increased mortality at 30 days, one year, and 6 years after stroke. ${ }^{13}$ Parsons et al. ${ }^{10}$ prospectively studied 63 acute stroke patients. Acute and subacute magnetic resonance spectroscopy was performed to assess the relationship between acute BG and lactate production in the ischemic region. $\mathrm{BG}$ concentrations $>130 \mathrm{mg} / \mathrm{dL}$ were present in $40 \%$ of admissions of the patients evaluated and remained high throughout the patient's hospital stay (mean $206 \mathrm{mg} / \mathrm{dL}$ ). Longer hospital stays (7 vs 6 days; $p=0.01$ ) and higher inpatient charges ( $\$ 6600$ vs $\$ 5200 ; p<0.01$ ) were noted in the hyperglycemia group.

Hypoglycemia causes alterations in brain electrical activity ranging from cortical slowing, burst suppression with associated seizure activity, to isoelectricity. ${ }^{62} \mathrm{Hypo-}$ glycemia evokes a centrally mediated stress counterregulatory response characterized by increased serum concentrations of epinephrine and norepinephrine. This response is seen even with minor changes in BG levels. Severe hypoglycemia with associated electroencephalographic flattening is accompanied by large increases in cerebral blood 
flow; however, changes in cerebral blood flow are more variable in less severe hypoglycemia. Decreased cerebral glucose uptake is seen during various degrees of hypoglycemia. Finally, hypoglycemia causes metabolic disturbances involving neuronal protein synthesis, amino acid metabolism, and $\mathrm{pH}$ homeostasis, along with neuronal necrosis and permanent neurologic damage in the most severe form of hypoglycemia. Due to the poor outcomes associated with glucose fluctuations, a microdialysis probe for monitoring glucose and lactate concentrations in the cerebral cortex has been studied in the neurosurgical population. ${ }^{63}$

There is some evidence that administering insulin during cerebral ischemia is beneficial; however, the detrimental effects of hypoglycemia such as brain damage must be considered. The safety of glucose-insulin-potassium (GIK) infusion was evaluated in 25 patients within 24 hours of ictus with hyperglycemia (127-309 mg/dL). Only one patient required treatment for symptomatic hypoglycemia. ${ }^{64}$ When hyperglycemia is present before an ischemic or anoxic event, neurologic damage is worse. ${ }^{62}$ These findings are more consistent in cases of global versus focal ischemia. Since hyperglycemia is clearly associated with poor neurologic outcome during cerebral ischemia, perhaps glucose-containing solutions should be withheld. However, as of May 24, 2004, there are no published studies evaluating the effects of elevated BG values on neurologic morbidity and mortality, and the role of insulin is not fully known.

\section{CARDIOVASCULAR}

Hyperglycemia has several effects on the myocardium resulting in oxidative stress and increased superoxide production in the mitochondria. Oxygen free radical formation may scavenge endogenous nitric oxide, increasing electrical instability of the heart and peripheral vascular tone. High sympathetic activity during an MI leads to increased production of free fatty acids, which increases myocardial oxygen requirements and decreases contractility. ${ }^{65,66}$ It is believed that patients with inadequate insulin response to hyperglycemia have impaired glucose oxidation in both ischemic and nonischemic areas of the myocardium, which increases oxygen-consuming fatty acid metabolism, thus increasing the risk of ischemia, decreased myocardial contraction, and arrhythmias ${ }^{67}$ The administration of glucose GIK infusions suppresses free fatty acid oxidation in MI patients, providing support for this theory ${ }^{68}$ The main effect of GIK therapy is believed to be administration of glucose to the ischemic myocardium ${ }^{69}$ Insulin itself may have a cardioprotective effect, as it reduces thromboxane $\mathrm{A}_{2}$ production and plasma plasminogen activator inhibitor-1 activity, thereby decreasing platelet aggregation and increasing fibrinolysis. ${ }^{46-48} \mathrm{~A}$ recent study in post-MI patients receiving standard therapy including thrombolytics and GIK infusions coroborates the evidence that insulin has antiinflammatory and profibrinolytic effects. ${ }^{70}$ Patients receiving GIK therapy had significantly lower C-reactive protein, serum amyloid $\mathrm{A}$, and plasminogen activator in- hibitor-1 levels. Insulin may also be a coronary vasodilator through the nitric oxide pathway in healthy individuals, as well as in patients with type 1 diabetes, obesity, and coronary artery disease. ${ }^{71}$

Reports of using GIK to support the failing heart after MI date back to the $1960 \mathrm{~s}^{72,73}$ Despite that long history, results from trials employing GIK in MI and cardiac surgery are often inconclusive due to small sample sizes and differences of study design and GIK infusions. ${ }^{74}$ The dose shown to suppress free fatty acid uptake in the myocardium is 30 $\mathrm{g}$ of glucose, 50 units of insulin, and $80 \mathrm{mmol}$ of potassium chloride per liter at $1.5 \mathrm{~mL} / \mathrm{kg} / \mathrm{h} .{ }^{68}$ A meta-analysis of randomized clinical trials involving GIK infusions in MI indicated a significant reduction in inpatient mortality for patients receiving GIK compared with conventional treatment. ${ }^{4}$ Major criticisms in the majority of trials include defective study design and concomitant therapies with predated thrombolytic and $\beta$-blocker therapies. ${ }^{74}$

Contemporary studies continue to show conflicting results with GIK infusions. In 1998, a study including 407 MI patients randomized to GIK or control showed a $66 \%$ reduction of in-hospital mortality when GIK was added to reperfusion therapy. ${ }^{75,76}$ The absolute mortality risk decreased from $15.2 \%$ in the control group to $5.2 \%$ in the GIK group. In 2003, GIK was studied in 940 MI patients receiving primary angioplasty. ${ }^{69}$ The infusion was titrated to maintain a BG level of $127-200 \mathrm{mg} / \mathrm{dL}$ for $8-12$ hours. Thirty-day mortality revealed a nonsignificant reduction between GIK therapy and placebo (4.8\% vs $5.8 \%$, respectively). The only significant decrease in mortality occurred in patients without signs of heart failure (Killip class 1), from $4.2 \%$ in the control group to $1.2 \%$ in the GIK group. In the control group, $67 \%$ of deaths were due to development of heart failure. ${ }^{76}$ There was no significant difference in mortality in patients with heart failure (Killip class $\geq 2$ ) receiving GIK.

The benefit of GIK therapy may be attributed to an improvement in ventricular function. A study of $37 \mathrm{MI}$ patients with primary angioplasty randomized to receive GIK or placebo revealed that GIK significantly increased left-ventricular ejection fraction from mean $\pm \mathrm{SD}, 39 \% \pm 12 \%$ at baseline to $51 \% \pm 13 \%$ at 3 months, while the placebo group increase was not significant (from $44 \% \pm 13 \%$ to $49 \% \pm$ $14 \%) .{ }^{77}$ Larger studies are needed to confirm these findings.

The benefit of glucose and insulin therapy has been studied in diabetic patients experiencing an MI. In the DIGAMI (Diabetes Insulin-Glucose in Acute Myocardial Infarction) trial, 620 diabetic patients were randomized to receive insulin and glucose infusion until the BG level was $128-199 \mathrm{mg} / \mathrm{dL}$. Subcutaneous injections of insulin were continued for 3 months. $^{78}$ Results at one year showed a statistically significant reduction in mortality from $26.1 \%$ in the conventional treatment group to $18.6 \%$ in the insulin group $(\mathrm{p}=0.027)$. The benefit was sustained for 3.5 years, with an $11 \%$ absolute risk reduction in mortality. ${ }^{79}$ The most pronounced reduction in mortality was in diabetic patients with a low cardiac risk profile who had received no previous insulin administration. 
GIK therapy remains controversial and not widely adopted due to conflicting reports. ${ }^{80}$ One explanation for the inconsistent findings may be the varying target BG concentrations in the clinical trials, from 120 to $200 \mathrm{mg} / \mathrm{dL}$. Recent studies raise the question of the most appropriate BG concentration in patients after an MI has occurred. A metaanalysis including $>6000$ patients revealed that stress hyperglycemia occurs in $71 \%$ of nondiabetic and $84 \%$ of diabetic patients experiencing an MI. ${ }^{9}$ The nondiabetic patients with $\mathrm{BG}$ concentrations $\geq 110 \mathrm{mg} / \mathrm{dL}$ had a 3.9-fold higher risk of death than patients with lower BG concentrations. Nondiabetic patients with admission BG concentrations $>145-181 \mathrm{mg} / \mathrm{dL}$ were at higher risk of congestive heart failure or cardiogenic shock. A recent study reconfirms that nonsurviving cardiac medical patients have significantly higher initial, mean, and maximum BG concentrations compared with survivors in the ICU. ${ }^{81}$ This trial supports further investigation into intensive glucose control with GIK therapy targeting BG concentrations $<110 \mathrm{mg} / \mathrm{dL}$ to improve outcomes in patients with MI.

\section{POSTOPERATIVE INFECTIONS}

Increasing evidence suggests that hyperglycemia impedes normal physiologic responses to infection. ${ }^{82-85}$ In vitro and in vivo studies report substantial impairment in immune function and wound healing associated with hyperglycemia. ${ }^{86-93}$ Mechanisms include complement inactivation, ${ }^{87,89}$ irregularities in granulocyte adherence, ${ }^{92,93}$ impaired phagocytosis, ${ }^{91,94}$ delayed chemotaxis and oxidative burst, ${ }^{95,96}$ and decreased bactericidal activity ${ }^{94,97}$ Collagen deposition is impaired, possibly due to decreased fibroblast proliferation. ${ }^{86}$ The degree of leukocyte abnormalities varies directly with $\mathrm{BG}$ concentrations ${ }^{98-100}$; impaired phagocytic function occurs with BG levels as low as $200 \mathrm{mg} / \mathrm{dL}^{15}$

Although numerous in vitro studies of the influence of hyperglycemia on immune function have been reported, few were conducted in a clinical setting. ${ }^{101-103}$ A prospective cohort study assessed the correlation between perioperative glucose control and the subsequent risk of infectious complications in 411 diabetic patients undergoing coronary artery surgery. ${ }^{101}$ Hyperglycemia was an independent predictor of short-term infectious complications. After adjusting for confounding variables, patients with mean BG concentrations $>200 \mathrm{mg} / \mathrm{dL}$ following surgery had higher rates of leg and chest wound infections, pneumonia, and urinary tract infections.

Zerr et al. ${ }^{102}$ evaluated the impact of an insulin protocol targeted at maintaining BG concentrations $<200 \mathrm{mg} / \mathrm{dL}$. A retrospective chart review was conducted including 9000 postoperative cardiac surgery patients, $18 \%$ of whom were diabetic. Elevated BG concentrations on the first and second postoperative days were associated with a higher incidence of deep sternal wound infections. BG concentrations $>200 \mathrm{mg} / \mathrm{dL}$ at 48 hours were significantly associated with increased risk of deep wound infection $(\mathrm{p}=0.002)$. The rate of deep sternal wound infections in diabetic patients decreased from $2.8 \%$ prior to implementation of the in- sulin protocol to $0.74 \%$ the third year after implementation $(p=0.14)$. In nondiabetic patients, the rate decreased from $0.4 \%$ to $0.31 \%$.

Similar results have been reported. In a prospective study of 2500 diabetic patients who underwent cardiac surgery, the impact of sliding scale insulin compared with continuous insulin infusions titrated to maintain BG concentrations at $150-200 \mathrm{mg} / \mathrm{dL}$ was evaluated. ${ }^{103} \mathrm{~A}$ significant reduction in the incidence of deep sternal wound infections $(0.8 \%$ vs $2 \%$; $p=0.01)$ was observed in the continuous-infusion group. Hyperglycemia in the immediate postoperative period was an independent predictor of infections.

\section{CRITICALLY ILL PATIENT POPULATION}

van den Berghe et al. ${ }^{104}$ investigated the value of insulin therapy directed at maintaining strict glucose control in 1500 patients admitted to the ICU. This study included both diabetic and nondiabetic patients, and the majority (63\%) had undergone cardiac bypass surgery. Patients were randomized to receive intensive insulin therapy (continuous infusions to maintain BG concentrations at 80-110 $\mathrm{mg} / \mathrm{dL}$ ) or conventional insulin therapy. Conventionally treated patients received continuous insulin infusions only if their BG concentration exceeded $215 \mathrm{mg} / \mathrm{dL}$ and the glucose target level was $180-200 \mathrm{mg} / \mathrm{dL}$. Interim analysis at one year demonstrated a significant reduction in ICU mortality (4.6 vs $8.0 \% ; \mathrm{p}=0.036$ ) with continuous infusion; the study was then terminated prematurely. The mortality benefit was especially evident among patients requiring intensive care for $>5$ days ( 10.6 vs $20.2 \% ; \mathrm{p}=0.005)$ and was achieved primarily through a reduced incidence of multisystem organ failure with a proven septic focus.

These findings were significant regardless of whether patients had a history of diabetes. Overall, in-hospital mortality was lower in the intensive insulin group. Intensive insulin treatment also reduced the risk of bloodstream infections and sepsis by $46 \%(p=0.003)$, renal dysfunction, and the need for red blood cell transfusions.

Similar results were reported in a retrospective review of $>1800$ critically ill medical and surgical patients $(22.4 \%$ diabetics) ${ }^{81}$ The lowest hospital mortality $(9.6 \%)$ occurred in patients with mean glucose concentrations between 80 and $99 \mathrm{mg} / \mathrm{dL}$. Mortality increased progressively with increases in mean glucose concentrations, and the highest mortality $(42.5 \%)$ was noted in patients with mean BG concentrations $>300 \mathrm{mg} / \mathrm{dL}$ ( $\mathrm{p}<0.001$ ). Importantly, these observations were consistent among all patient subgroups; there was no difference in mortality based on the presence or absence of diabetes.

Clinical studies demonstrate that GIK solutions improve outcomes in thermal injury and sepsis. Bronsveld et al. ${ }^{105}$ studied the effects of GIK (1 g/kg of glucose $50 \%$; insulin 1.5 units $/ \mathrm{kg}$; potassium chloride $10 \mathrm{mEq}$ ) in 15 patients with septic shock who, despite volume replacement and vasopressors, had persistent hypotension and lactic acidosis. GIK infusion increased cardiac index, but it was only significant for patients with a lower cardiac index at base- 
line $(\mathrm{p}<0.01)$. Mean arterial and pulmonary artery pressures did not change. The observation period was only 30 minutes after GIK infusion. Another study evaluated the effect of GIK as adjunctive treatment in 17 early burn patients. ${ }^{106}$ GIK infusions for 15 minutes $(100 \mathrm{~mL}$ of glucose $50 \%$; insulin 75 units; potassium chloride $10 \mathrm{mEq}$ ) resulted in significant increases in cardiac index $(\mathrm{p}<0.01)$, stroke volume $(\mathrm{p}<0.05)$, left-ventricular stroke work $(\mathrm{p}<$ $0.05)$, and decreased systemic vascular resistance ( $\mathrm{p}<$ $0.05)$ compared with baseline values. The urine volume also increased after GIK therapy compared with the baseline volume $(p<0.01)$. Although these investigators administered insulin, they did not use a goal-directed insulin infusion algorithm to achieve preset BG concentrations.

It is uncertain whether euglycemia or the protective effects of insulin confer the reported morbidity and mortality benefits. Two recent studies provide insight into this controversy. One study attempted to define the factors that determine insulin requirements and establish whether reductions in mortality and morbidity were a result of insulin infusion or prevention of hyperglycemia. ${ }^{107}$ In this study, insulin requirements were highest and most variable during the first 6 hours of intensive care. Multivariate logistic regression analysis indicated that lowered BG concentrations rather than insulin dose corresponded to decreased mortality ( $\mathrm{p}<$ $0.0001)$, critical illness polyneuropathy ( $p<0.0001)$, bacteremia $(p=0.02)$, and inflammation $(p=0.0006)$, but not to prevention of renal failure. The insulin dose was an independent determinant in prevention of renal failure $(\mathrm{p}=$ 0.03 ). Among the relevant findings in those investigators' original study ${ }^{\mathbf{1 0 4}}$ was the significant reduction in the incidence of acute renal failure requiring renal replacement therapy in the treatment group. These beneficial clinical effects could be explained by the antiinflammatory properties of insulin and the recent finding that insulin has potent anti-apoptotic effects. ${ }^{108}$ In contrast, high glucose concentrations produce apoptotic effects in tubular epithelial cells. ${ }^{109}$ Thus, insulin may minimize the damage associated with cytokine-induced cellular dysfunction and cell death and may have an important role in prevention of renal failure.

A recent prospective observational study demonstrated that it is the control of BG concentrations, not insulin administration, that is associated with reduced mortality and morbidity in ICU patients. ${ }^{110}$ Relationship between ICU outcome and degree of BG control and insulin administration was modeled using multivariate logistic regression. At prevailing BG concentrations of 111-144 mg/dL, increased insulin administration was positively and significantly associated with ICU mortality. This was observed in both diabetic and nondiabetic patients.

\section{POTENTIAL FOR HYPOGLYCEMIA}

Hypoglycemia is a serious consequence of insulin therapy that could lead to neurologic sequelae. The definition of hypoglycemia differs in insulin therapy trials, making it difficult to compare rates of hypoglycemia. Van den Berghe et al. ${ }^{107}$ reported that the incidence of hypoglycemia, de- fined as a BG level $\leq 40 \mathrm{mg} / \mathrm{dL}$, was $5.2 \%$ in intensive insulin-treated patients versus $0.8 \%$ in conventionally treated patients. In a national survey, Cohen et al. ${ }^{111}$ found that $11 \%$ of serious medication errors resulted from insulin misadministration. The Joint Commission on Accreditation of Healthcare Organizations mandates that efforts made to improve the safety of using high-alert medications (eg, insulin) are documented. Proactive planning to reduce insulin misadministration includes spelling rather than abbreviating dosage units to avoid potential for an overdose. Although time consuming, a check system for infusion pump rates and concentration settings should be instituted to avoid infusion-pump programming errors. Hypoglycemic episodes can be prevented with proactive systematic changes and avid monitoring.

\section{Summary}

The patient population in the van den Berghe et al. ${ }^{104}$ trial was limited to those undergoing surgery, mostly cardiac surgery; these results cannot be extrapolated to patients in nonsurgical ICUs or to those with other types of critical illness. A recent study of intensive insulin therapy to maintain normoglycemia resulted in significant reductions in morbidity and mortality in a more heterogeneous population of medical and surgical critically ill patients. ${ }^{81}$ Similar to the van den Berghe et al. trial, these authors demonstrated that even a modest elevation of BG to $>99 \mathrm{mg} / \mathrm{dL}$ during ICU stay was associated with increased hospital mortality. This study included almost twice as many diabetics as did the van den Berghe et al. trial. Based on available literature, it appears that control of BG concentration-not insulin administration - confers the mortality benefit. Optimal benefits appear to be achieved with maintenance of BG concentrations $<100-110 \mathrm{mg} / \mathrm{dL}$. Furthermore, it seems prudent to control glucose, regardless of a history of diabetes.

Prospective, randomized controlled studies of sufficient sample size to provide a power analysis for evaluation of critically ill patient subsets are needed in adult and pediatric patients to compare conventional methods of glucose control with normoglycemia in a broad patient population. The potential for improvement in ICU patient outcomes, combined with the economics of implementing therapy with a low-cost drug, make intensive insulin therapy an attractive option.

Implementing protocols that optimize target BG concentrations has great potential for positively improving patient outcomes in the ICU. These protocols should be updated as needed based on evolving literature on the topic. Future studies are needed in other ICU populations in order to evaluate both the clinical and economic impact of these guidelines.

Kelly S Lewis PharmD, at time of writing, Associate Professor of Anesthesiology, Division of Critical Care, Rush Presbyterian St. Luke's Medical Center, Chicago, IL; now, Medical Science Liaison, Actelion Pharmaceuticals US, Inc.

Sandra L Kane-Gill PharmD MSc, Assistant Professor, School of Pharmacy, University of Pittsburgh, Center for Pharmacoinformatics and Outcomes Research, Pittsburgh, PA 
Mary Beth Bobek PharmD, Director, Cardiovascular Pharmacotherapy, Department of Cardiac Services, New Hanover Regional Medical Center, Wilmington, NC

Joseph F Dasta MSc FCCM, Professor of Pharmacy, College of Pharmacy, The Ohio State University, Columbus, $\mathrm{OH}$

Reprints: Sandra L Kane-Gill PharmD MSc, School of Pharmacy, University of Pittsburgh, Center for Pharmacoinformatics and Outcomes Research, 904 Salk Hall, 3501 Terrace St., Pittsburgh, PA 15261-0001, fax 412/624-1850, kanesi@msx.upmc.edu

\section{References}

1. Dasta JF, Durtschi AJ, Kane-Gill SL. Pharmacoeconomics in critical care. In: Grenvik A, ed. Textbook of critical care. 5th ed. Amsterdam: Elsevier, 2004 (in press).

2. Weber RJ, Kane SL, Oriolo VA, Saul M, Skledar SJ, Dasta JF. Impact of intensive care unit (ICU) drug use on hospital costs: a descriptive analysis with recommendations for optimizing ICU pharmacotherapy. Crit Care Med 2003;31(1 suppl):S17-24

3. Dasta JF, Cooper LM. Impact of drotrecogin alfa (activated) on resource use and implication for reimbursement. Pharmacotherapy 2002;(12 part 2):216S-22S

4. Das UN. Insulin and the critically ill. Crit Care 2002;6:262-3.

5. Mizock BA. Alterations in fuel metabolism in critical illness: hyperglycaemia. Best Pract Res Clin Endocrinol Metab 2001;15:533-51.

6. Gore DC, Chinkes D, Heggers J, Herndon DN, Wolfe SE, Desai M. Association of hyperglycemia with increased mortality after severe burn injury. J Trauma 2001;51:540-4.

7. Ljungqvist $\mathrm{O}$, Nygren J, Thorell A. Insulin resistance and elective surgery. Surgery 2000;128:757-60.

8. Kagansky N, Levy S, Knobler H. The role of hyperglycemia in acute stroke. Arch Neurol 2001;58:1209-12.

9. Capes SE, Hunt D, Malmerg K, Gerstein HC. Stress hyperglycemia and increased risk of death after myocardial infarction in patients with and without diabetes: a systematic overview. Lancet 2000;355:773-8

10. Parsons MW, Barber PA, Desmond PM, Baird TA, Darby DG, Byrnes $\mathrm{G}$, et al. Acute hyperglycemia adversely affects stroke outcome: a magnetic resonance imaging and spectroscopy study. Ann Neurol 2002;52: 20-8.

11. Weir CJ, Murray GD, Dyker AG, Lees KR. Is hyperglycaemia an independent predictor of poor outcome after acute stroke? Results of a longterm follow up study. BMJ 1997;314:1303-6.

12. Malmberg K, Norhammar A, Wedel H, Ryden L. Glycometabolic state at admission: important risk marker of mortality in conventionally treated patients with diabetes mellitus and acute myocardial infarction: longterm results from the Diabetes and Insulin-Glucose Infusion in Acute Myocardial Infarction (DIGAMI) study. Circulation 1999;99:2626-32.

13. Williams LS, Rotich J, Qi R, Fineberg N, Espay A, Bruno A, et al. Effects on admission hyperglycaemia on mortality and costs in acute ischemic stroke. Neurology 2002;59:67-71.

14. Zindrou D, Taylor KM, Bagger JP. Admission plasma glucose: an independent risk factor in nondiabetic women after coronary artery bypass grafting. Diabetes Care 2001;24:1634-9.

15. McMahon MM, Bistrian BR. Host defenses and susceptibility to infection in patients with diabetes mellitus. Infect Dis Clin North Am 1995;9: $1-9$.

16. Carter EA. Insulin resistance in burns and trauma. Nutr Rev 1998;56:(1 pt 2):S170-6.

17. Ljungqvist O, Sandberg E, Nylander G, Ware J. Glucose kinetics in haemorrhagic hyperglycemia. Circ Shock 1989;28:347-56.

18. Thorell A, Nygren J, Ljungqvist O. Insulin resistance: a marker of surgical stress. Curr Opin Clin Nutr Metab Care 1999;2:69-78.

19. Thorell A, Loftenius A, Andersson B, Ljungqvist O. Postoperative insulin resistance and circulating concentrations of stress hormones and cytokines. Clin Nutr 1996;15:55-9.

20. Jeevanandam M, Young DH, Schiller WR. Glucose turnover, oxidation, and indices of recycling in severely traumatized patients. J Trauma Inj Infec Crit Care 1990;30:582-9.

21. Gelfand RA, Matthews DE, Bier DM, Sherwin RS. Role of counterregulatory hormones in the catabolic response to stress. J Clin Invest 1984; 74:2238-48.

22. Shamoon H, Hendler R, Sherwin RS. Synergistic interactions among anti-insulin hormone in the pathogenesis of stress hyperglycemia in humans. J Clin Endocrinol Metab 1981;52:1235-41.

23. McGuinness OP, Fugiwara T, Murrell S, Bracy D, Neal D, O'Connor D, et al. Impact of chronic stress hormone infusion on hepatic carbohydrate metabolism in the conscious dog. Am J Physiol 1993;265(2 pt 1):E314-22.

24. Wolfe RR. Herman Award Lecture, 1996: relation of metabolic studies to clinical nutrition - the example of burn injury. Am J Clin Nutr 1996; 64:800-8.

25. Jahoor F, Herndon DN, Wolfe RR. Role of insulin and glucagons in the response of glucose and alanine kinetics in burn injured patients. J Clin Invest 1986;78:807-14

26. Hotamisligil GS, Spiegelman BM. Tumor necrosis factor alpha: a key component of the obesity-diabetes link. Diabetes 1994;43:1271-8.

27. Sherwin RS, Sacca L. Effect of epinephrine on glucose metabolism in humans: contribution of the liver. Am J Physiol 1984;247(2 pt 1):E157-65.

28. Connolly CC, Steiner KE, Stevenson RW, Neal DW, Williams PE, Alberti KG, et al. Regulation of lipolysis and ketogenesis by norepinephrine in conscious dogs. Am J Physiol 1991;261(4 pt 1):E466-72.

29. Montori VM, Basu A, Erwin PJ, Velosa JA, Gabriel SE, Kudva YC. Posttransplantation diabetes: a systematic review of the literature. Diabetes Care 2002;25:583-93.

30. Ekstrand AV. Effect of steroid therapy on insulin sensitivity in insulindependent diabetic patients after kidney transplantation. J Diab Complications 1991;5:244-8.

31. Kwoun MO, Ling PR, Lydon E, Imrich A, Qu Z, Palombo J, et al. Immunologic effects of acute hyperglycemia in nondiabetic rats. JPEN J Parenter Enteral Nutr 1997;21:91-5.

32. Frankenfield DC, Reynolds HN, Badellino NM, Wiles CE. Glucose dynamics during continuous hemodiafiltration and total parenteral nutrition. Intensive Care Med 1995;21:1016-22.

33. Manji S, Shikora S, McMahon M, Blackburn GL, Bistrian BR. Peritoneal dialysis for acute renal failure: overfeeding resulting from dextrose absorbed during dialysis. Crit Care Med 1990;18:29-31.

34. Engquist A, Brandt MR, Fernandes A, Kehlet H. The blocking effect of epidural analgesia on the adrenocortical and hyperglycemic responses to surgery. Acta Anaesthesiol Scand 1977;21:330-5.

35. Kehlet H, Brandt MR, Prange-Hansen A, Alberti KG. Effect of epidural analgesia on metabolic profiles during and after surgery. Br J Surg 1979;66:543-6.

36. Giesecke K, Hamberger B, Jarnberg PO, Klingstedt C, Persson B. Highand low-dose fentanyl anaesthesia: hormonal and metabolic responses during cholecystectomy. Br J Anaesth 1988;61:575-82.

37. Schricker T, Carli F, Sheiber M, Wachter U, Geisser W, Lattermann R, et al. Propofol/sufentanil anesthesia suppresses the metabolic and endocrine response during, not after, lower abdominal surgery. Anesth Analg 2000;90:450-5.

38. Lattermann R, Schricker T, Wachter U, Georgieff M, Goertz A. Understanding the mechanisms by which isoflurane modifies the hyperglycemic response to surgery. Anesth Analg 2001;93:121-7.

39. Werb MR, Zinman B, Teasdale SJ, Goldman BS, Scully HE, Marliss EB. Hormonal and metabolic responses during coronary artery bypass surgery: role of infused glucose. J Clin Endocrinol Metab 1989;69:10108.

40. Shangraw RE, Jahoor F, Miyoshi H, Neff WA, Stuart CA, Herndon DN, et al. Differentiation between septic and postburn insulin resistance. Metabolism 1989;38:983-9.

41. Rao V, Merante F, Weisel RD, Shirai T, Ikonomidis JS, Cohen G, et al. Insulin stimulates pyruvate dehydrogenase and protects human ventricular cardiomyocytes from simulated ischemia. J Thorac Cardiovasc Surg 1998;116:485-94.

42. Sakurai Y, Aarsland A, Herndon DN, Chinkes DL, Pierre E, Nguyen TT, et al. Stimulation of muscle protein synthesis by long-term insulin infusion in severely burned patients. Ann Surg 1995;222:283-97.

43. Aarsland A, Chinkes D, Wolfe RR, Barrow RE, Nelson SO, Pierre E, et al. Rate of hepatic very low density lipoprotein triglyceride secretion remains unchanged. Ann Surg 1996;223:777-89.

44. Hansen TK, Thiel S, Wouters PJ, Christiansen JS, Van den Berghe G. Intensive insulin therapy exerts anti-inflammatory effects in critically il patients and counteracts the adverse effect of low mannose-binding lectin levels. J Clin Edocrinol Metab 2003;88:1082-8.

45. Das UN. Current advances in sepsis and septic shock with particular emphasis on the role of insulin. Med Sci Monit 2003;9:RA181-92.

46. Davi G, Catalano I, Averna M, Notarbartolo A, Stano A, Ciabattoni G, et al. Thromboxane biosynthesis and platelet function in type II diabetes mellitus. N Engl J Med 1990;322:1769-74. 
47. Vague P, Raccah D, Juhan-Vague I. Hemobiology, vascular disease, and diabetes with special reference to impaired fibrinolysis. Metabolism 1992;41(suppl):2-6.

48. Jain SK, Nagi DK, Slavin BM, Lumb PJ, Yudkin JS. Insulin therapy in type 2 diabetic subjects suppresses plasminogen activator inhibitor (PAI1) activity and proinsulin-like molecules independently of glycaemic control. Diabet Med 1993;10:27-32.

49. Satomi N, Sakurai A, Haranaka K. The relationship of hypoglycemia to tumor necrosis factor production and antitumor activity: the role of glucose, insulin, and macrophages. J Natl Cancer Inst 1985;74:1255-60.

50. Das UN. Is insulin an anti-inflammatory molecule? Nutrition 2001;17: 409-13.

51. Woo E, Chan YW, Yu YL, Huang CY. Admission glucose level in relation to mortality and morbidity outcome in 252 stroke patients. Stroke 1988;19:185-91.

52. Rovlias A, Kotsou S. The influence of hyperglycemia on neurologic outcome in patients with severe head injury. Neurosurgery 2000;46:335-43.

53. Ginsberg MD, Prado R, Dietrich WD, Busto R, Waton BD. Hyperglycemia reduces the extent of cerebral infarction in rats. Stroke 1987 18:570-4.

54. Venables GS, Miller SA, Gibson G, Hardy JA, Strong AJ. The effects of hyperglycaemia on changes during reperfusion following focal cerebral ischaemia in the cat. J Neurol Neurosurg Psychiatry 1985;48:663-9.

55. Chew W, Kucharczyk J, Moseley M, Derugin N, Norman D. Hyperglycemia augments ischemic brain injury: in vivo MR imaging/spectroscopic study with nicardipine in cats with occluded middle cerebral arteries. AJNR Am J Neuroradiol 1991;12:603-9.

56. DeCourten-Meyers GM, Kleinholz M, Wagner KR, Myers RE. Normoglycemia (not hypoglycemia) optimizes outcome from middle cerebral artery occlusion. J Cereb Blood Flow Metab 1994;14:227-36.

57. Prado R, Ginsberg MD, Dietrich WD, Watson BD, Busto R. Hyperglycemia increases infarct size in collaterally perfused but not end-arterial vascular territories. J Cereb Blood Flow Metab 1988;8:186-92.

58. Warner DS, Todd MM, Dexter F, Ludwig P, McAllister AM. Temporal thresholds for hyperglycemia-augmented ischemic brain damage in rats. Stroke 1995;26:655-60.

59. Pulsinelli WA, Waldman S, Rawlinson D, Plum F. Moderate hyperglycemia augments ischemic brain damage: a neuropathologic study in the rat. Neurology 1982;32:1239-46.

60. Anderson RE, Tan WK, Martin HS, Meyer FB. Effects of glucose and $\mathrm{PaO}_{2}$ modulation on cortical intracellular acidosis, NADH redox state, and infarction in the ischemic penumbra. Stroke 1999;30:160-70.

61. Bruno BA, Levin MR, Frankel MR, Brott TG, Lin Y, Tilley BC, et al. Admission glucose level and clinical outcomes in the NINDS rt-PA stroke trial. Neurology 2002;59:669-74.

62. Sieber FE, Traystman RJ. Special issues: glucose and the brain. Crit Care Med 1992;20:104-14.

63. Goodman JC, Valadaka AB, Gopinath SP, Uzura M, Robertson CS. Extracellular lactate and glucose alterations in the brain after head injury measured by microdialysis. Crit Care Med 1999;27:1965-73.

64. Scott JF, Robinson GM, French JM, O'Connell JE, Alberti KG, Gray CS. Glucose potassium insulin infusions in the treatment of acute stroke patients with mild to moderate hyperglycemia: the Glucose Insulin Stroke Trial (GIST). Stroke 1999;30:793-9.

65. Gupta DK, Jewitt DE, Young R, Hartog M, Opie LH. Increased plasmafree-fatty-acid concentrations and their significance in patients with acute myocardial infarction. Lancet 1969;2:1209-13.

66. Valori C, Thomas M, Shillingford J. Free noradrenaline and adrenaline excretion in relation to clinical syndromes following myocardial infarction. Am J Cardiol 1967;20:605-17.

67. Oliver MF, Opie LH. Effects of glucose and fatty acids on myocardial ischaemia and arrhythmias. Lancet 1994;343:155-8.

68. Rackley CE, Russel R, Rogers WJ, Mantle JA, McDaniel HG, Papapietro SE. Clinical experience with glucose-insulin-potassium therapy in acute myocardial infarction. Am Heart J 1981;102(6 pt 1):1038-49.

69. Van der Horst IC, Zijlstra F, Van'tHof AW, Doggen CJ, deBoer MJ, Suryapranata $\mathrm{H}$, et al. Glucose-insulin-potassium infusion in patients treated with primary angioplasty for acute myocardial infarction: the Glucose-Insulin-Potassium study: a randomized trial. J Am Coll Cardiol 2003;42:784-91.

70. Chaudhuri A, Janicke D, Wilson MF, Tripathy D, Garg R, Bandyopadhyay A, et al. Anti-inflammatory and profibrinolytic effect of insulin in acute ST-segment-elevation myocardial infarction. Circulation 2004; 109:849-54.
71. Sundell J, Knuuti J. Insulin and myocardial blood flow. Cardiovasc Res 2003;57:312-9.

72. Sievers J, Lindh J, Johanson BW, Karnell J. Acute myocardial infarction treated by glucose-insulin-potassium (GIK) infusion. Cardiology 1966; 49:239-47.

73. Pentacost BL, Mayne NM, Lamb P. Controlled trial of intravenous glucose, potassium, and insulin in acute myocardial infarction. Lancet 1968; 1:946-8.

74. Fath-Ordoubadi F, Beatt KJ. Glucose-insulin-potassium therapy for treatment of acute myocardial infarction: an overview of randomized placebo-controlled trials. Circulation 1997;96:1152-6.

75. Diaz R, Paolasso E, Piegas LS, Tajer CD, Morena MG, Corvalan R, et al. Metabolic modulation of acute myocardial infarction. The ECLA (Estudios Cardiologicos Latinoamerica) Collaborative Group. Circulation 1998;98:2227-34.

76. Apstein CS. The benefits of glucose-insulin-potassium for acute myocardial infarctions (and some concerns). J Am Coll Cardiol 2003;42: $792-5$.

77. Castro PF, Larrain G, Baeza R, Corbalan R, Nazzal C, Greig DP, et al. Effects of glucose-insulin-potassium solution on myocardial salvage and left ventricular function after primary angioplasty. Crit Care Med 2003;31:2152-5.

78. Malmberg K, Ryden L, Efendic S, Herlitz J, Nicol P, Waldenstrom A, et al. Randomized trial of insulin-glucose infusion followed by subcutaneous insulin treatment in diabetic patients with acute myocardial infarction (DIGAMI study): effects on mortality at 1 year. J Am Coll Cardiol 1995;26:57-65.

79. Malmberg K. Prospective randomized study of intensive insulin treatment on long term survival after acute myocardial infarction in patients with diabetes mellitus. BMJ 1997;314:1512-5.

80. Doenst T, Bothe W, Beyersdorf F. Therapy with insulin in cardiac surgery: controversies and possible solutions. Ann Thorac Surg 2003;75: S721-8.

81. Krinsley JS. Association between hyperglycemia and increased hospital mortality in a heterogeneous population of critically ill patients. Mayo Clin Proc 2003;78:1471-8.

82. Zacharias A, Habib RH. Factors predisposing to median sternotomy complications. Deep vs superficial infection. Chest 1996;110:1173-8.

83. L'Ecuyer PB, Murphy D, Little JR, Fraser VJ. The epidemiology of chest and leg wound infections following cardiothoracic surgery. Clin Infect Dis 1996;22:424-9.

84. Shimada M, Matsumata T, Akazawa K, Kamakura T, Itasaka H, Sugimachi K, et al. Estimation of risk of major complications after hepatic resection. Am J Surg 1991;167:399-403.

85. Fietsam R, Bassett J, Glover JL. Complications of coronary artery surgery in diabetic patients. Am Surg 1991;57:551-7.

86. Black E, Vibe-Petersen J, Jorgensen LN, Madsen SM, Argen MS, Holstein PE, et al. Decrease of collagen deposition in wound repair in type 1 diabetes independent of glycemic control. Arch Surg 2003;138:34-40.

87. Black CT, Hennessey PJ, Andrassy RJ. Short-term hyperglycemia depresses immunity through nonenzymatic glycosylation of circulating immunoglobulin. J Trauma 1990;30:830-2.

88. Port D, Schwartz MW. Diabetes complications: why is glucose potentially toxic? Science 1996;272:699-700.

89. Hostetter MK. Handicaps to host defense. Effects of hyperglycemia on C3 and Candida albicans. Diabetes 1990;39:271-5.

90. Hennessey PJ, Black CT, Andrassy RJ. Nonenzymatic glycosylation of immunoglobulin G impairs complement fixation. J Parenter Enteral Nutr 1991;15:60-4.

91. Rassias AJ, Givan AL, Marrin CA, Whalen K, Pahl J, Yeager MP. Insulin increases neutrophil count and phagocytic capacity after cardiac surgery. Anesth Analg 2002;94:1113-9.

92. Bagdade JD, Root RK, Bulger RJ. Impaired leukocyte function in patients with poorly controlled diabetes. Diabetes 1974;23:9-15.

93. Bagdade JD, Stewart M, Walters E. Impaired granulocyte adherence. A reversible defect in host defense in patients with poorly controlled diabetes. Diabetes 1978;27:677-81.

94. Sima AA, O’Neill SJ, Naimark D, Yagihashi S, Klass D. Bacterial phagocytosis and intracellular killing by alveolar macrophages in BB rats. Diabetes 1988;37:544-9.

95. Mowat A, Baum J. Chemotaxis of polymorphonuclear leukocytes from patients with diabetes mellitus. N Engl J Med 1971;284:621-7.

96. Delamaire M, Maugendre D, Moreno M, LeGoff MC, Allanie H, Genetet B. Impaired leucocyte functions in diabetic patients. Diabet Med 1997; 14:29-34. 
97. Nolan CM, Beaty HN, Bagdade JD. Further characterization of the impaired bactericidal function of granulocytes in patients with poorly controlled diabetes. Diabetes 1978;27:889-94.

98. Davidson NJ, Sowden JM, Fletcher J. Defective phagocytosis in insulin controlled diabetics: evidence for a reaction between glucose and opsonising proteins. J Clin Pathol 1984;37:783-6.

99. Drachman RH, Root RK, Wood WB. Studies on the effect of experimental nonketotic diabetes mellitus on antibacterial defense. J Exp Med 1966; 124:227-40.

100. MacRury SM, Gemmell CG, Paterson KR, MacCuish AC. Changes in phagocytic function with glycaemic control in diabetic patients. J Clin Pathol 1989;42:1143-7.

101. Golden SJ, Peart-Vigilance C, Kao WH, Brancati FL. Perioperative glycemic control and the risk of infectious complications in a cohort of adults with diabetes. Diabetes Care 1999;22:1408-14.

102. Zerr KJ, Furnary AP, Grunkemeier GL, Bookin S, Kanhere V, Starr A. Glucose control lowers the risk of wound infection in diabetics after open heart operations. Ann Thorac Surg 1997;63:352-61.

103. Furnary AP, Zerr KJ, Grunkemeier GL, Starr A. Continuous intravenous insulin infusion reduces the incidence of deep sternal wound infection in diabetic patients after cardiac surgical procedures. Ann Thorac Surg 1999;67:352-62.

104. van den Berghe G, Wouters P, Weekers F, Verwaest C, Bruyninckx F, Schetz M, et al. Intensive insulin therapy in critically ill patients. $\mathrm{N}$ Engl J Med 2001;345:1359-67.

105. Bronsveld W, Van den Bos GC, Thijs LG. Use of glucose-insulinpotassium (GIK) in human septic shock. Crit Care Med 1985;13:56670.

106. Kobayashi H, Yoshioka T, Maemura K, Ohashi N, Sawada Y, Sugimoto T. Hemodynamic and diuretic effects of GIK (glucose-insulin-potassium) treatment on extensive burn patients. J Trauma Injury Infect Crit Care 1983;23:116-22.

107. van den Berghe G, Wouters PJ, Bouillon R, Weekers F, Verwaest C, Schetz M, et al. Outcome benefit of intensive insulin therapy in the critically ill: insulin dose versus glycemic control. Crit Care Med 2003;31: 359-66.

108. Augustin R, Pocar P, Wrenzycki C, Niemann H, Fischer B. Mitogenic and anti-apoptotic activity of insulin on bovine embryos produced invitro. Reproduction 2003;126:91-9.

109. Allen DA, Harwood S, Varagunam M, Raftery MJ, Yaqoob MM. High glucose-induced oxidative stress causes apoptosis in proximal tubular epithelial cells and is mediated by multiple caspases. FASEB J 2003;17: 908-10.

110. Finney SJ, Zekveld C, Elia A, Evans TW. Glucose control and mortality in critically ill patients. JAMA 2003;290:2041-7.

111. Cohen MR, Proulx SM, Crawford SY. Survey of hospital system and common serious medication errors. J Healthc Risk Manag 1998;18:16-27.

\section{EXTRACTO}

OBJECTIVO: Evaluar los resultados clínicos en cuanto el control glucémico relacionado a la terapia intensiva de insulina y recomendar su lugar en el manejo de pacientes con enfermedades aguda críticas.

FUENTES DE INFORMACIÓN: Se realizó búsquedas en el banco de datos de MEDLINE (1966 a marzo del 2004), la Biblioteca de Cochrane, y un repaso manual extensivo de los extractos usando términos claves tales como hiperglucemia, insulina, unidad de cuido intensivo, enfermedades aguda críticas, resultados clínicos, y guiás e algoritmos.
SELECCIÓN DE ESTUDIOS Y EXTRACCIÓN DE DATOS: Todos los artículos identificados de las fuentes de información fueron evaluados y juzgados ser relevantes si incluyeron y determinaron resultados clínicos.

SÍNTESIS DE DATOS: La mortalidad entre pacientes con enfermedades aguda críticas prolongadas excede un $20 \%$, y la mayoría de las muertes han sido atribuídas al sepsis y falla orgánica multisistémica. La hiperglucemia es común en pacientes con enfermedades aguda críticas, aun en aquellos sin un historial de diabetes mellitus. El mantenimiento de la normoglucemia con el uso de insulina en pacientes con enfermedades aguda críticas ha producido mejoras en los resultados neurológicos, cardiovasculares, e infecciosos. Sobre todo, se puede reducir la morbilidad y la mortalidad con el uso de la terapia agresiva de insulina. La implantación de ésta información en protocolos para mantener el control estricto de glucosa ha sido bien recibida y segura.

CONCLUSIONES: El uso de protocolos de insulina en pacientes críticamente enfermos puede mejorar el control sanguíneo de glucosa y reducir la morbilidad y mortalidad en esta población. Se recomienda la introducción de protocolos de insulina para controlar los niveles de glucosa con el propósito de obtener un estado de euglucemia, independientemente del historial diabético. Se requiere una supervisión frecuente e imprescindible para evitar la hipoglucemia.

Carlos C da Camara

RÉSUMÉ

OBJECTIF: Évaluer les bénéfices cliniques associés au contrôle de la glycémie avec une insulinothérapie intensive et recommander son utilisation chez les patients de soins intensifs.

REVUE DE LITTERATURE: Une recherche dans les bases MEDLINE (1966 à mars 2004) et Cochrane ainsi qu'un dépouillement manuel extensif de résumés ont été effectués en utilisant les mots clés suivants: hyperglycémie, insuline, unité de soins intensifs, patients de soins intensifs, lignes directrices, et algorithmes. Tous les articles ont été évalués et jugés pertinents s'ils traitaient d'issues cliniques.

RESUME: Le taux de mortalité chez les patients effectuant un séjour prolongé aux soins intensifs dépasse les $20 \%$ et la plupart des décès est attribuable à la septicémie et à l'insuffisance multi-organique. L'hyperglycémie est fréquente chez ces patients, même chez ceux sans histoire de diabète sucré. Le maintien d'une glycémie normale avec l'insuline s'est révélé efficace pour améliorer les issues neurologiques, cardiovasculaires, et infectieuses. La morbidité et la mortalité sont diminuées par l'utilisation d'une insulinothérapie intensive.

CONCLUSIONS: L'utilisation de protocoles d'insuline chez les patients de soins intensifs améliore le contrôle de la glycémie et réduit la morbidité et la mortalité. La mise en place de protocoles d'insuline visant la normalisation de la glycémie chez les patients de soins intensifs est recommandée et ce peu importe la présence ou non de diabète sucré dans les antécédents du patient. Une surveillance étroite de la glycémie est nécessaire afin d'éviter l'hypoglycémie.

Alain Marcott 